\title{
The Role of Population and Half-Sib Family on Driving Suitable Functional Traits for Quercus suber L. Forest Restoration
}

\author{
Luna Morcillo $^{1, *}$, Hassane Moutahir ${ }^{2}{ }^{(\mathbb{C}}$, Jordi Cortina ${ }^{2}$ and Alberto Vilagrosa ${ }^{1,2, *(1)}$ \\ 1 Mediterranean Center for Environmental Studies (CEAM Foundation), Joint Research Unit University of \\ Alicante-CEAM, Ctra. Sant Vicent del Raspeig s/n, Sant Vicent del Raspeig, 03690 Alicante, Spain \\ 2 Department of Ecology, University of Alicante, Ctra. Sant Vicent del Raspeig s/n, Sant Vicent del Raspeig, \\ 03690 Alicante, Spain; hassane.moutahir@ua.es (H.M.); jordi@ua.es (J.C.) \\ * Correspondence: luna@ua.es (L.M.); a.vilagrosa@ua.es (A.V.); Tel.: +34-96-590-9521
}

Received: 23 April 2020; Accepted: 12 June 2020; Published: 15 June 2020

\begin{abstract}
Research Highlights: Seedlings of different Quercus suber L. populations and half-sib families differ in their response to multiple stressors, which may have consequences on the future distribution of this Mediterranean species. Background and Objectives: Global change will likely increase the frequency and severity of drought in drylands. Plant species' distributions will largely depend on their ability to respond to the combined effect of drought and other environmental stressors. Genetic diversity in morpho-functional traits are key components of this response. Yet, information on the response to multiple stresses is scarce for many iconic species. The present study assessed the variability in the response of populations and half-sib families of a Mediterranean acidophilous tree, cork oak, to drought and changes in soil conditions. Materials and Methods: We sampled acorns of half-sib families from two cork oak populations genetically introgressed with the alkaline-tolerant species Quercus ilex L., and from a non-introgressed cork oak population located in its core habitat. We germinated the acorns and subjected seedlings to contrasted levels of water availability and additions of calcium and magnesium carbonate, and assessed their morpho-physiological response. Results: Response to drought and soil chemistry composition differed between populations and families. For some traits, introgressed populations responded similarly to drought than the non-introgressed population. Conversely, the response to soil chemistry was not clearly related to introgression. When considering half-sib families within populations, the population effect diminished, which revealed the importance of intra-population variation. However, relevant traits for water scarcity adaptations, such as specific leaf area and root:shoot ratio, remained significantly different at the population level, which highlights the relevance of these traits for management. Conclusions: Our study shows that the adaptive management and restoration of cork oak forests should consider not only geographic provenances, but also half-sib lines within populations.
\end{abstract}

Keywords: drought adaptation; forest restoration; genetic introgression; global change; Mediterranean forest; morpho-functional traits; Quercus suber; soil chemistry

\section{Introduction}

The Mediterranean basin will be highly vulnerable to global change due to the combination of different pressures [1]. This region is already subject to seasonal and interannual droughts, which modulate plant population dynamics by limiting plant productivity [2] and compromising the survival of adult trees [3]. Other biotic and abiotic stress factors, such as warm temperatures, soil properties, and interaction with herbivores and pathogens, will interact with drought to control the distribution 
and functioning of Mediterranean forests [4-7]. With future conditions, these factors are expected to increase in intensity and recurrence, which will make these forests more vulnerable [8].

Despite the growing interest in predicting the impact of climate change on tree species distribution [9,10], the distribution of common Mediterranean trees remains unclear [11]. This is particularly true for the iconic Quercus suber L. (hereafter, cork oak) [12]. Cork oak is a widely distributed tree species in the Mediterranean basin that covers ca. 2.5 million ha from 0 to 1300 m.a.s.l. In its distribution area, rainfall ranges from 600 to $1000 \mathrm{~mm}$ and mean annual temperature ranges from $13{ }^{\circ} \mathrm{C}$ to $20^{\circ} \mathrm{C}$ [13]. This species is of particular interest for its high ecological and economic relevance, as it provides multiple important ecosystem services [14]. It is also considered a fire-resistant species and is the only European tree with aboveground sprouting capability after crown fire [15]. The conservation and restoration of cork oak forests could increase the resistance and the resilience of Mediterranean landscapes to wildfire. However, the dynamics of cork oak forests in forthcoming decades may be at risk from rising adult mortality rates, overgrazing, and a lack of regeneration [16,17]. Decline has been linked to various interacting processes related to climate change, such as the increasing frequency of extreme droughts and pathogen attacks $[18,19]$. Selecting reproductive material from locally well-adapted populations can enhance the success of restoration actions, as ecotypes vary strongly in their resilience to environmental disturbances and stress. [20]. Consequently, using seedlings from local populations should be a common practice in most situations [21]. However, species' capacity to cope with changes in the amount and distribution of rainfall with warming is hard to predict [22], and assisted migration by means of restoration (i.e., human-assisted migration of plants to suitable habitats) may contribute to the conservation of this species and cork oak forests $[23,24]$.

The physiological and morphological traits of Mediterranean vegetation, such as those related to stomatal response and photosynthesis (e.g., stomatal conductance, photosynthesis, or water use efficiency) or those linked to plant vigor (e.g., plant biomass allocation and growth), have been interpreted by some authors in order to understand plant responses to short-term stress episodes, such as summer drought $[25,26]$ or soil chemistry alterations [27]. Nevertheless, for the long-term survival of Mediterranean species like cork oak, sufficient genetic diversity may also be required [28]. It is known that strong adaptive genetic differentiation can occur on small geographical scales (i.e., within populations) and might be more related to environmental than spatial distances [29]. Local adaptation is not always predominant in wild populations, especially in small ones [30], and using local populations does not ensure restoration success [31]. Therefore, alternative procedures to select plant material that consider genetic diversity could substantially increase the chances of success in restoration projects under the current and future harsh conditions [32,33].

Cork oak generally grows on acidic soils over granite, schist, or sandstone, but sometimes occurs on limestone-derived soils or alkaline soils overlying dolomitic bedrocks, as in some eastern Spain populations [27]. Cork oak's adaptive capacity to withstand different soil conditions may be partly conferred by genetic introgression (i.e., the integration of foreign genes into a recipient species' gene pool as a result of backcrossing hybrid offspring with a parental species) with Quercus ilex $\mathrm{L}$. (hereafter, holm oak). Introgression is considered an evolutionarily important process that contributes to adaptation [34]. This may occur through either the transfer of adaptive traits of one species to another or by novel adaptive variation [35]. Moreover, the gene flow among species boundaries might promote colonising abilities [36] as the populations hybridising (or having experienced introgression) may become genetically differentiated from non-hybridising populations by acquiring new allelic variants or genes [37]. This process may have contributed in the past to cork oak's success under adverse coil and climate conditions (e.g., during the glacial pulses of the Pleistocene [38] or in isolated decarbonated areas surrounded by basic soils on dolomitic bedrock [39]). Previous studies have shown that completely replacing cork oak chloroplast DNA (cpDNA) with that of holm oak has been observed exclusively in eastern Spain populations, and in French-Catalonian and southeastern Morocco populations [40-42]. Indeed, the fragmented cork oak forest complex found in Spain is of 
interest for studying cork oak genetic variation and its implication for the future of these populations facing uncertain climate conditions [43].

In the present study, we assessed between- and within-population variability in morpho-functional traits of cork oak seedlings in response to drought and soil chemistry. Here, we tested whether there was intra- or inter-population-level variation in several plant traits related to water stress responses and soil chemistry. We specifically explored whether: (1) the changes in trait values from two introgressed cork oak populations differed from those of one non-introgressed population in response to limited water availability; (2) if cork oak seedlings from introgressed populations, growing on neutral to slightly alkaline $\mathrm{pH}$ soils, differed from those of the non-introgressed population that develops on acidic $\mathrm{pH}$ soils in their response to the addition of $\mathrm{Mg}$ and $\mathrm{Ca}$, which confers alkaline $\mathrm{pH}$ conditions to the soil. Considering that holm oak is more tolerant to drought and soil alkalinity than cork oak, we hypothesised that the introgressed populations would show higher adaptation to water scarcity and $\mathrm{Mg}$ and Ca inputs. These hypotheses provide evidence for the evolution of holm oak-like morphotypes in cork oak and its future implications for its capacity to adapt to new climates and soil conditions in a forest restoration context.

\section{Materials and Methods}

\subsection{Study Area}

To carry out this experiment, we sampled acorns from three different cork oak populations in Spain, which were all native populations: Toledo population $\left(39^{\circ} 36^{\prime} 33^{\prime \prime} \mathrm{N}, 4^{\circ} 54^{\prime} 18^{\prime \prime} \mathrm{W}\right)$, located in this species' core distribution area in Spain and corresponds to the western pure cork oak (i.e., non-introgressed with holm oak) populations; Calderona ( $\left.39^{\circ} 43^{\prime} 45^{\prime \prime} \mathrm{N}, 0^{\circ} 29^{\prime} 34^{\prime \prime} \mathrm{W}\right)$ and Espadà populations $\left(39^{\circ} 52^{\prime} 0^{\prime \prime} \mathrm{N}, 0^{\circ} 17^{\prime} 30^{\prime \prime} \mathrm{W}\right)$, both from the eastern stable hybrid populations introgressed with holm oak cpDNA [38]. The Toledo bioclimatic conditions correspond to the Mesomediterranean zone (mean annual temperature of $15{ }^{\circ} \mathrm{C}$, mean January temperature of $6{ }^{\circ} \mathrm{C}$, mean July temperature of $26^{\circ} \mathrm{C}$ ), with a mean annual precipitation of $389 \mathrm{~mm}$ and a de Martonne aridity index (IDM, precipitation/temperature +10 [44]) that equals 15.6. The Calderona and Espadà populations are in the Thermomediterranean zone. The Calderona population has a mean annual temperature of $16{ }^{\circ} \mathrm{C}$, a mean January temperature of $9{ }^{\circ} \mathrm{C}$, and a mean July temperature of $24{ }^{\circ} \mathrm{C}$, a mean annual precipitation of $450 \mathrm{~mm}$ and an IDM of 17.3. The Espadà population has a mean annual temperature of $15^{\circ} \mathrm{C}$, a mean January temperature of $8{ }^{\circ} \mathrm{C}$, and a mean July temperature of $23^{\circ} \mathrm{C}$, a mean annual precipitation of $483 \mathrm{~mm}$ and an IDM of 19.3. According to precipitation records and IDM, Toledo is the driest population and Espadà is the wettest, with Calderona occupying an intermediate position. All the climate data were obtained from the closest weather station to each population (Agroclimatic Information System, SIAR Net, for the period 2001-2019).

\subsection{Experimental Design and Measurements}

The experimental material consisted of five open pollinated maternal half-sib families from each population. In each population, we selected mother trees separated by more than $100 \mathrm{~m}$ from one another to avoid inbreeding [45] and collected 250 acorns per tree. The experimental design consisted of a complete randomized block design where each block was a 35-cell nursery tray $\left(305 \mathrm{~cm}^{3}\right.$, Super-leach ${ }^{\circledR}$ ), where only 15 cells were occupied (three populations $\times$ five half-sib families). One replicate of the experiment comprised four trays (15 individuals $\times$ four treatments $=60$ seedlings) which where then replicated 10 times. Each tray was randomly assigned to a location in the nursery. Moreover, the tray location was modified monthly to reduce the effect of local environmental conditions. Similar sized acorns were individually sown in the containers and filled with washed quartz sand, peat, and coco peat (1:1:1 in volume) fertilized by the manufacturer $\left(57 \mathrm{mg}\right.$ of $\mathrm{NO}_{3}{ }^{-}, 69 \mathrm{mg}$ of $\mathrm{NH}_{4}{ }^{+}$, $60 \mathrm{mg}$ of $\mathrm{P}, 344 \mathrm{mg}$ of $\mathrm{K}$ per L of substrate). Seedlings were kept under natural daylight in a public 
forest nursery (Vivero Forestal Sta. Faz, Alicante, SE Spain; 38 $23^{\prime} 28^{\prime \prime} \mathrm{N}, 0^{\circ} 26^{\prime} 48^{\prime \prime} \mathrm{E}$ at 50 m.a.s.1) in a semiarid climate, with a mean annual precipitation of $353 \mathrm{~mm}$ and a mean air temperature of $18^{\circ} \mathrm{C}$.

Three months after sowing, we manipulated the seedlings' abiotic conditions by applying four different watering and soil-enrichment treatments: (1) control treatment (Co), with no soil nutrient composition alterations and regular irrigation to field capacity once a week in spring and autumn, and twice a week in summer; (2) drought treatment (D), with no soil nutrient composition alterations and half the irrigation of the control (i.e., substrate water content around 50\% of field capacity); (3) Ca treatment $(\mathrm{Ca})$ with inputs of manually applied powdery $\mathrm{CaCO}_{3}(2.5 \mathrm{~g}$ per seedling once a month during the study period) to simulate the cork oak seedlings developing on limestone; (4) $\mathrm{Mg}$ treatment $(\mathrm{Mg})$ with inputs of manually applied powdery $\mathrm{MgCO}_{3}(2.5 \mathrm{~g}$ per seedling once a month during the study period) to simulate the cork oak seedlings developing on dolomites. The water irrigation regime in the $\mathrm{Ca}$ and $\mathrm{Mg}$ treatments was the same as in the control treatment. All the seedlings were fertilised monthly with modified Hoagland's solution containing $150 \mathrm{mg} \mathrm{N} \mathrm{L}^{-1}$ (as Ca $\left(\mathrm{NO}_{3}\right)^{2}$ and $\mathrm{KNO}_{3}$ ), $80 \mathrm{mg} \mathrm{P} \mathrm{L}^{-1}$ (as $\mathrm{KH}_{2} \mathrm{PO}_{4}$ ), and $100 \mathrm{mg} \mathrm{K} \mathrm{L}^{-1}$.

Eleven months after sowing, and immediately before harvesting, seedling morphology was characterised by measuring the plant height $(\mathrm{H})$ and basal diameter $(\mathrm{BD})$ of 10 randomly selected seedlings per half-sib family (10 seedlings $\times$ five half-sib families $\times$ three populations $\times$ four treatments $=600$ replicates in all). Physiological measurements were taken of five randomly selected seedlings per half-sib family (300 seedlings in all). Stomatal conductance (gs), net photosynthesis rate (A), and transpiration (T) were measured with a portable IRGA LiCor-6400 (Li-Cor Inc., Lincoln, NE, USA) and instantaneous water use efficiency (WUEi) was calculated as the ratio between the photosynthesis and transpiration rates. All the physiological measurements were taken under optimal conditions (sunny days and well irrigated seedlings, and thus also from re-watered plants in the drought treatment). Finally, after harvesting, leaves were separated from the stem and scanned, and the leaf area was calculated by using an image analysis software (WinRhizo, Regent Instruments Inc., Quebec, Canada). The dry weight of stems, leaves, tap roots, and fine roots were calculated after drying samples in an oven for $72 \mathrm{~h}$ at $70^{\circ} \mathrm{C}$. The fine root:shoot ratio (R:S) was derived from individual weights. The specific leaf area (SLA) was calculated as the ratio between the leaf dry weight and the leaf area of a representative fully developed leaf per plant, and of the same plants chosen for the gas exchange measures.

\subsection{Data Analyses}

Treatment effects were analysed by using the general linear model (ANOVA) on the cork oak trait data with two different approaches: (1) assessing differences among populations in response to water availability and soil chemistry by considering two fixed factors: population (with three levels) and treatment (with four levels); (2) assessing within-population differences in response to water availability and soil chemistry by considering population and treatment as the fixed factors and half-sib family (with five levels) as the random factor nested within population. We applied Tukey's honestly significant difference (HSD) tests for the mean pairwise multiple comparisons. These analyses were performed with the SPSS v.25.0 statistical package (IBM SPSS Statistics for Windows, Armonk, NY, USA; IBM Corp.). The homogeneity of variances was tested by Levene's test, and the data of the heterocedastic variables were conveniently transformed. Finally, to reduce the dimensionality of the morpho-functional traits and visualise the performance of the different populations and half-sib families, we performed a principal component analysis (PCA) and hierarchical clustering on the data for each half-sib family to be treatment averaged across replications (see Table S1 for eigenvalues and Figure S1 for dendrograms in the Supplementary Material). The PCA was carried out on scaled and centred data using the prcomp function from the $\mathrm{R}$ "stats" package [46], which examines covariances/correlations between individuals. Hierarchical clustering was done by the $\mathrm{R}$ "pvclust" package [47], which uses bootstrap resampling techniques to compute probability values ( $p$-values) for each hierarchical cluster. Closely related clusters with high $p$-values (generally $\geq 95 \%$ ) were considered 
to be strongly supported by the data to assess the choice of the different clusters in the dendrograms. The visualisation of the different clusters was done by using ellipses on the PCA plots.

\section{Results}

\subsection{Seedling Response to Drought and Soil Chemistry at the Population Level}

The cork oak seedlings were taller for Espadà and larger in basal diameter for both the Espadà and Calderona populations. On average, the Toledo population had smaller seedlings with lower growth rates for both aboveground variables, while the root:shoot (R:S) ratio indicated greater belowground biomass allocation in the seedlings of this population (Tables 1 and 2, Figure S2 in the Supplementary Materials). The SLA resulted in lower values for Toledo than for the other two populations (Tables 1 and 2, Figure S2 in the Supplementary Materials). Regarding ecophysiological variables, values were higher for the Toledo population in gs and WUEi than for the Calderona and Espadà populations. The opposite occurred for the photosynthesis rates (A) and transpiration ( $\mathrm{Tr}$ ), which were higher for Espadà than for Toledo and Calderona (Tables 1 and 2, Figure S2 in the Supplementary Materials).

Table 1. Trait values (mean $\pm \mathrm{SE}$ ) of 11-month old cork oak (Quercus suber) seedlings from three populations in response to drought and soil chemistry (Co, control; $\mathrm{D}$, drought; $\mathrm{Mg}, \mathrm{MgCO}_{3}$ inputs; $\mathrm{Ca}$, $\mathrm{CaCO} 3$ inputs) (see Table 2 for the statistical analysis).

\begin{tabular}{|c|c|c|c|c|c|c|c|c|c|}
\hline & & $\mathbf{H}$ & BD & R:S & SLA & gs & $\operatorname{Tr}$ & $\mathbf{A}$ & WUEi \\
\hline \multirow{4}{*}{ Toledo } & Co & $13.2 \pm 0.5$ & $3.7 \pm 0.1$ & $6.5 \pm 0.2$ & $69.0 \pm 1.4$ & $0.112 \pm 0.008$ & $2.25 \pm 0.83$ & $6.06 \pm 0.94$ & $3.72 \pm 0.52$ \\
\hline & D & $12.5 \pm 0.3$ & $3.5 \pm 0.1$ & $6.2 \pm 0.2$ & $67.6 \pm 1.1$ & $0.118 \pm 0.009$ & $1.42 \pm 0.05$ & $5.92 \pm 0.63$ & $4.35 \pm 0.38$ \\
\hline & $\mathrm{Mg}$ & $12.8 \pm 0.4$ & $3.6 \pm 0.1$ & $6.6 \pm 0.2$ & $71.5 \pm 3.2$ & $0.112 \pm 0.003$ & $0.99 \pm 0.34$ & $3.53 \pm 0.46$ & $4.87 \pm 0.55$ \\
\hline & $\mathrm{Ca}$ & $13.0 \pm 0.4$ & $3.7 \pm 0.1$ & $7.1 \pm 0.3$ & $68.9 \pm 2.2$ & $0.140 \pm 0.015$ & $1.71 \pm 0.60$ & $4.48 \pm 0.69$ & $3.87 \pm 0.49$ \\
\hline \multirow{4}{*}{ Calderona } & Co & $12.8 \pm 0.4$ & $3.8 \pm 0.1$ & $5.2 \pm 0.6$ & $73.9 \pm 2.5$ & $0.112 \pm 0.062$ & $1.55 \pm 0.63$ & $3.10 \pm 0.75$ & $3.41 \pm 0.55$ \\
\hline & D & $11.9 \pm 0.3$ & $3.9 \pm 0.1$ & $4.9 \pm 0.2$ & $72.7 \pm 2.5$ & $0.099 \pm 0.013$ & $2.77 \pm 0.88$ & $7.55 \pm 0.88$ & $3.53 \pm 0.42$ \\
\hline & $\mathrm{Mg}$ & $12.0 \pm 0.3$ & $3.6 \pm 0.1$ & $5.7 \pm 0.3$ & $75.7 \pm 2.4$ & $0.112 \pm 0.007$ & $2.05 \pm 0.63$ & $5.71 \pm 0.81$ & $2.78 \pm 0.29$ \\
\hline & $\mathrm{Ca}$ & $13.9 \pm 0.4$ & $4.3 \pm 0.1$ & $6.0 \pm 0.3$ & $71.9 \pm 2.2$ & $0.104 \pm 0.005$ & $0.95 \pm 0.19$ & $3.56 \pm 0.46$ & $4.27 \pm 1.02$ \\
\hline \multirow{4}{*}{ Espadà } & Co & $15.5 \pm 0.5$ & $4.2 \pm 0.1$ & $5.2 \pm 0.3$ & $75.9 \pm 2.1$ & $0.118 \pm 0.014$ & $3.61 \pm 1.02$ & $8.55 \pm 1.14$ & $2.63 \pm 0.31$ \\
\hline & D & $14.1 \pm 0.5$ & $4.0 \pm 0.1$ & $5.1 \pm 0.3$ & $78.8 \pm 2.1$ & $0.098 \pm 0.006$ & $1.69 \pm 0.30$ & $6.40 \pm 0.74$ & $3.71 \pm 0.34$ \\
\hline & $\mathrm{Mg}$ & $13.4 \pm 0.3$ & $3.6 \pm 0.1$ & $6.1 \pm 0.3$ & $77.4 \pm 1.8$ & $0.095 \pm 0.011$ & $0.82 \pm 0.32$ & $2.52 \pm 0.40$ & $3.44 \pm 0.53$ \\
\hline & $\mathrm{Ca}$ & $14.1 \pm 0.4$ & $3.7 \pm 0.1$ & $5.9 \pm 0.2$ & $74.0 \pm 1.6$ & $0.138 \pm 0.020$ & $3.57 \pm 0.94$ & $8.98 \pm 1.01$ & $2.97 \pm 0.26$ \\
\hline
\end{tabular}

Units: height, $\mathrm{H}(\mathrm{cm})$; basal diameter, $\mathrm{BD}(\mathrm{mm})$; root shoot ratio, R:S (unitless); specific leaf area, $\mathrm{SLA}\left(\mathrm{cm}^{2} \mathrm{~g}^{-1}\right)$; stomatal conductance, gs $\left(\mathrm{mol} \mathrm{m}^{-2} \mathrm{~s}^{-1}\right)$; transpiration rate, $\operatorname{Tr}\left(\mathrm{mmol} \mathrm{H} \mathrm{O} \mathrm{m}^{-2} \mathrm{~s}^{-1}\right)$; net photosynthesis rate, A $\left(\mu \mathrm{mol} \mathrm{m} \mathrm{m}^{-2} \mathrm{~s}^{-1}\right)$; instantaneous water use efficiency, WUEi $\left(\mu \mathrm{molCO}_{2} \mathrm{mmolH}_{2} \mathrm{O}^{-1}\right)$.

Table 2. Summary statistics of the general linear model and $p$-values (F) for the effect of the different populations (Toledo, T; Calderona, C; Espadà, E) and treatments (control, $\mathrm{Co}$; drought, D; $\mathrm{MgCO}_{3}$, $\mathrm{Mg}$; and $\mathrm{CaCO}_{3}, \mathrm{Ca}$ ) on cork oak (Quercus suber) seedling performance. Numbers in bold indicate significant effects $(p<0.05)$ and italics denote marginally significant effects $(0.05<p<0.1)$. Post hoc results can be found in Figure S2 in the Supplementary Materials.

\begin{tabular}{cccc}
\hline Variable & Population $(\mathbf{P})$ & Treatment $(\mathrm{T})$ & $\mathbf{P} \times \mathbf{T}$ \\
\hline $\mathrm{H}$ & $\mathbf{1 7 . 4 5 ( < 0 . 0 0 1 )}$ & $\mathbf{5 . 9 7 ( 0 . 0 0 1 )}$ & $\mathbf{2 . 3 7 ( 0 . 0 2 9 )}$ \\
$\mathrm{BD}$ & $\mathbf{6 . 5 5 ( 0 . 0 0 2 )}$ & $\mathbf{5 . 5 3 ( 0 . 0 0 1 )}$ & $\mathbf{5 . 6 1 ( < 0 . 0 0 1 )}$ \\
R:S & $\mathbf{2 5 . 5 5 ( < 0 . 0 0 1 )}$ & $\mathbf{9 . 5 1 ( < 0 . 0 0 1 )}$ & $0.53(0.789)$ \\
SLA & $\mathbf{1 1 . 1 5 ( < 0 . 0 0 1 )}$ & $1.10(0.351)$ & $0.45(0.845)$ \\
gs & $\mathbf{3 . 7 4 ( 0 . 0 2 5 )}$ & $\mathbf{3 . 6 5 ( 0 . 0 1 3 )}$ & $2.03(0.062)$ \\
Tr & $\mathbf{6 . 9 9 ( 0 . 0 0 1 )}$ & $\mathbf{6 . 6 0 ( < 0 . 0 0 1 )}$ & $\mathbf{1 1 . 0 3 ( < 0 . 0 0 1 )}$ \\
$\mathrm{A}$ & $\mathbf{6 . 0 0 ( 0 . 0 0 3 )}$ & $\mathbf{6 . 9 1 ( < 0 . 0 0 1 )}$ & $\mathbf{9 . 0 3}(<\mathbf{0 . 0 0 1 )})$ \\
WUEi & $\mathbf{4 . 9 6 ( 0 . 0 0 8 )}$ & $0.99(0.399)$ & $1.63(0.139)$ \\
\hline
\end{tabular}

The drought treatment negatively affected seedling aboveground growth in both the height and basal diameter variables and had a neutral effect on the R:S ratio compared to the control treatment. 
Regarding the ecophysiological variables, drought had a negative effect on gs and a neutral effect on A and $\operatorname{Tr}$ (Table 2, Figure S2 in the Supplementary Materials).

The addition of $\mathrm{MgCO}_{3}$ inputs also negatively affected the growth of both height and basal diameter and had neutral effect on the R:S ratio. In the ecophysiological traits, $\mathrm{Mg}$ had a negative effect on A and Tr and a neutral effect on gs compared to the control treatment (Table 2, Figure S2 in the Supplementary Materials).

Finally, the addition of $\mathrm{CaCO}_{3}$ inputs had a neutral effect on the growth of both the height and basal diameter variables, and a positive effect on belowground biomass, with higher R:S ratios than the control. Regarding the ecophysiological variables, Ca caused a positive effect on gs and no effect on A and Tr. No differences were found for SLA and WUEi for any applied treatment (Figure S2 in the Supplementary Materials).

\subsection{Seedling Response to Drought and Soil Chemistry at the Half-Sib Family Level}

The analysis considering half-sib families within populations revealed major changes in some results compared to the previous section (Table 2; Table 3). Regarding morphological traits, the half-sib family became crucial for establishing differences in seedling height and basal diameter within a population, and also for establishing differences in the R:S ratio. For the ecophysiological variables, half-sib family was significant for A, while gs and WUEi were only marginally significant $(p<0.07)$ and had no effect on $\operatorname{Tr}$ (Table 3). However, the R:S ratio and SLA maintained statistical differences at the population level, and Toledo differed from the other two populations.

Table 3. Summary statistics of the general linear model and $p$-values (F) for the effect of the half-sib family within populations, the different populations (Toledo, T; Calderona, C; Espadà, E), and treatments (Control, $\mathrm{Co}$; Drought, $\mathrm{D} ; \mathrm{MgCO}_{3}, \mathrm{Mg}$; and $\mathrm{CaCO}_{3}, \mathrm{Ca}$ ) on cork oak (Quercus suber) seedling performance. The numbers in bold indicate significant effects $(p<0.05)$ and italics denote marginally significant effects $(p<0.1)$. Different letters denote significant differences in the post hoc test $(p<0.05)$ and "nd" denotes no differences $(p>0.1)$.

\begin{tabular}{ccccccc}
\hline Variable & $\begin{array}{c}\text { Half-Sib Family } \\
(\mathbf{F})\end{array}$ & $\begin{array}{c}\text { Population } \\
(\mathbf{P})\end{array}$ & $\begin{array}{c}\text { Treatment } \\
(\mathbf{T})\end{array}$ & $\mathbf{F} \times \mathbf{T}$ & $\mathbf{P} \times \mathbf{T}$ & Post Hoc Test \\
\hline $\mathrm{H}$ & $\mathbf{3 . 9 1 ( 0 . 0 0 1 )}$ & $2.37(0.135)$ & $2.21(0.105)$ & $\mathbf{2 . 8 8 ( < 0 . 0 0 1 )}$ & $0.99(0.442)$ & $\begin{array}{c}\text { nd } \\
\text { nd }\end{array}$ \\
\hline BD & $\mathbf{8 . 2 2 ( < 0 . 0 0 1 )}$ & $0.69(0.518)$ & $\mathbf{3 . 0 9 ( 0 . 0 4 0 )}$ & $\mathbf{1 . 6 4 ( 0 . 0 1 4 )}$ & $\mathbf{4 . 2 5 ( 0 . 0 0 3 )}$ & $\begin{array}{c}\mathrm{nd} \\
\mathrm{Co}(\mathrm{a}) ; \mathrm{Ca}(\mathrm{a}) ; \mathrm{D}(\mathrm{a}) ; \mathrm{Mg}(\mathrm{b})\end{array}$ \\
\hline $\mathrm{R}: \mathrm{S}$ & $\mathbf{2 . 3 9 ( 0 . 0 2 2 )}$ & $\mathbf{6 . 8 1 ( 0 . 0 1 1 )}$ & $\mathbf{5 . 4 2 ( 0 . 0 0 4 )}$ & $\mathbf{1 . 8 3 ( 0 . 0 0 3 )}$ & $0.17(0.983)$ & $\begin{array}{c}\mathrm{T}(\mathrm{a}) ; \mathrm{E}(\mathrm{b}) ; \mathrm{C}(\mathrm{b}) \\
\mathrm{Ca}(\mathrm{a}) ; \mathrm{Mg}(\mathrm{a}) ; \mathrm{Co}(\mathrm{b}) ; \mathrm{D}(\mathrm{b})\end{array}$ \\
\hline SLA & $1.62(0.130)$ & $\mathbf{4 . 7 8 ( 0 . 0 3 4 )}$ & $0.70(0.557)$ & $\mathbf{1 . 6 0 ( 0 . 0 2 2 )}$ & $0.34(0.910)$ & $\begin{array}{c}\mathrm{T}(\mathrm{b}) ; \mathrm{C}(\mathrm{a}) ; \mathrm{E}(\mathrm{a}) \\
\mathrm{nd}\end{array}$ \\
\hline $\mathrm{gs}$ & $1.92(0.066)$ & $1.42(0.278)$ & $2.65(0.064)$ & $\mathbf{1 . 5 8 ( 0 . 0 2 6 )}$ & $1.45(0.224)$ & $\begin{array}{c}\mathrm{nd} \\
\mathrm{nd}\end{array}$ \\
\hline Tr & $0.90(0.554)$ & $1.65(0.232)$ & $1.87(0.154)$ & $\mathbf{1 7 . 3 1 ( < 0 . 0 0 1 )}$ & $\mathbf{2 . 4 4 ( 0 . 0 4 6 )}$ & $\begin{array}{c}\mathrm{nd} \\
\mathrm{nd}\end{array}$ \\
\hline $\mathrm{A}$ & $\mathbf{2 . 1 7 ( 0 . 0 3 9 )}$ & $0.87(0.444)$ & $\mathbf{2 . 8 9 ( 0 . 0 5 0 )}$ & $\mathbf{6 . 0 1 ( < 0 . 0 0 1 )}$ & $\mathbf{3 . 3 3 ( 0 . 0 1 1 )}$ & $\mathrm{D}(\mathrm{a}) ; \mathrm{Co}(\mathrm{ab}) ; \mathrm{Ca}(\mathrm{b}) ; \mathrm{Mg}(\mathrm{c})$ \\
\hline $\mathrm{WUEi}$ & $1.96(0.062)$ & $0.95(0.412)$ & $0.33(0.801)$ & $\mathbf{6 . 8 0 ( < 0 . 0 0 1 )}$ & $0.58(0.746)$ & $\begin{array}{l}\mathrm{nd} \\
\mathrm{nd}\end{array}$ \\
\hline
\end{tabular}

Differences among treatments were also affected by the half-sib family factor. The significance of several traits, such as height and stomatal conductance, was lost as regards the treatments in this analysis (Table 3). The negative effect of seedling $\mathrm{BD}$ and $\mathrm{A}$ remained with $\mathrm{MgCO}_{3}$ addition. As in the previous statistical analysis by population, the R:S ratio was positively affected by $\mathrm{CaCO}_{3}$ addition. In the analysis that considered half-sib family, this trait was also positively affected by $\mathrm{MgCO}_{3}$ addition. One of the key points in this analysis was that the half-sib family and treatment 
interaction was significant for all the assessed variables, and reflected that not all the half- sib families within each population displayed the same pattern of responses to drought and soil chemistry (Table 3, Figure 1, Figure S3 in the Supplementary Materials). On the contrary, population by treatment was only significant for BD and A. Including half-sib family in the statistical model produced a slight decrease in the power to detect differences between populations and treatments.
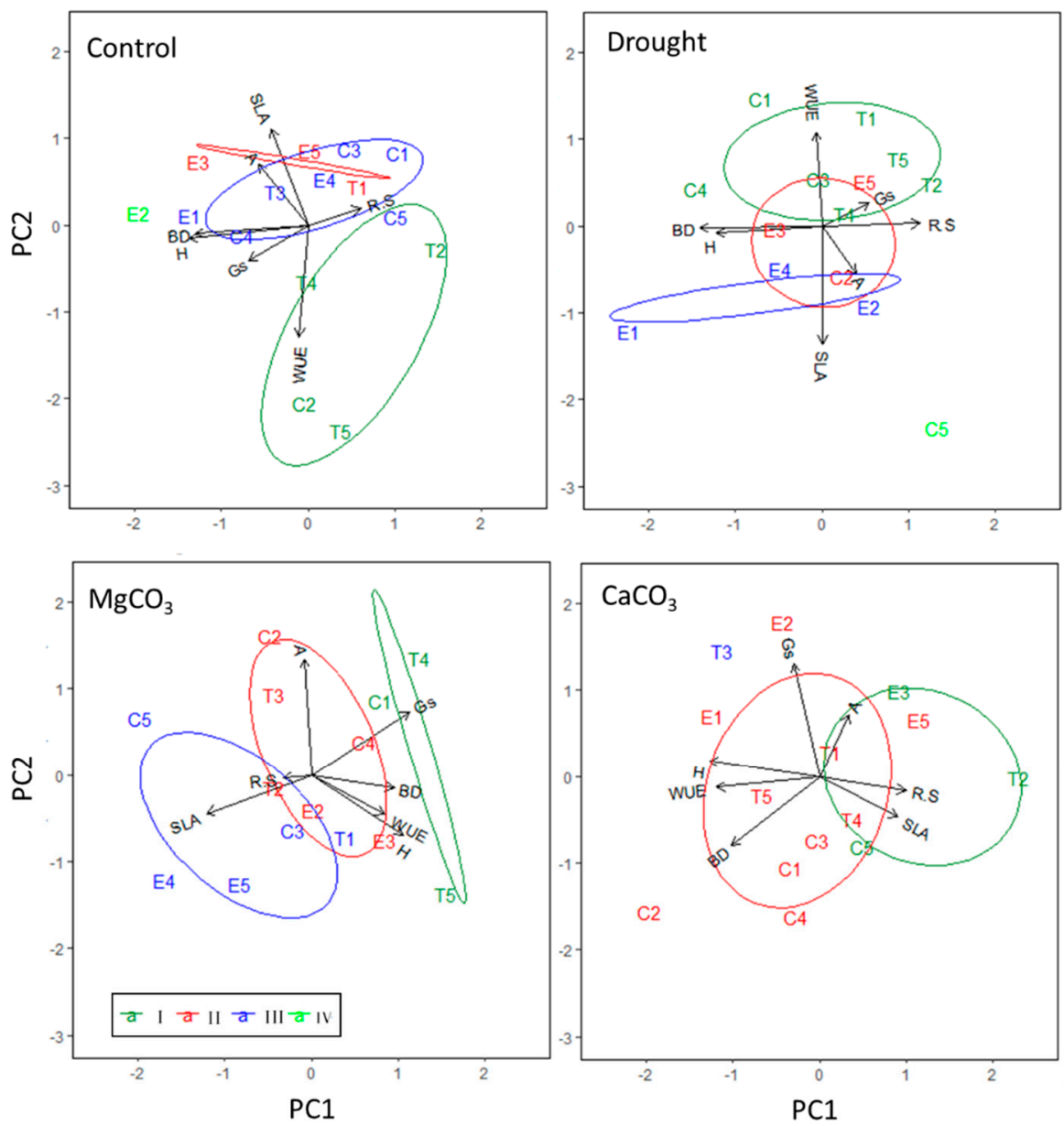

Figure 1. Principal component analysis (PCA) of seven plant traits (seedling height, basal diameter, root:shoot ratio, specific leaf area, photosynthesis rate, stomatal conductance, instantaneous water use efficiency) in the seedlings of five half-sib families within populations for each applied treatment. Principal components 1 and 2 in the control treatment explained $32 \%$ and $24 \%$ of variance, respectively, in treatment drought with $34 \%$ and $22 \%$, respectively, with $\mathrm{Mg}$ inputs $37 \%$ and $21 \%$, respectively, and with Ca inputs $40 \%$ and 21\%, respectively. Half-sib families (T1 to T5, C1 to C5, E1 to E5) refer to the half-sib families within the Toledo, Calderona, and Espadà populations, respectively. Different coloured ellipses delimited the half-sib families' clustering based on the Euclidean distances estimated by hierarchical dendrograms (Figure S1 in the Supplementary Materials).

Different patterns of response among half-sib families were confirmed by the PC analysis when the half-sib family scores were plotted on the principal components (Figure 1, Table S1 in the Supplementary Materials). For the control treatment, three main groups were identified and plotted according to the cluster analysis (Figure 1, Figure S1 in the Supplementary Materials). Cluster I was formed mainly by the combination of Toledo and some Calderona half-sib families. This cluster was related to WUEi and inversely to SLA in PC2, which explained 24\% of total trait variation (Table S1 in the Supplementary Materials). Clusters II and III were related mainly to some half-sib families from Espadà and others from Calderona along PC1, which explained 32\% of trait variation and had high 
negative variable loadings of $\mathrm{H}$ and $\mathrm{BD}$ related to some half-sib families from the Espadà population, e.g., half-sib families E1 and E2 (Table S1 in the Supplementary Materials).

For drought treatment, PC1 explained 34\% of variability and it had high positive loadings of R:S that correlated oppositely with the high negative loadings of H and BD (Table S1 in the Supplementary Materials). PC2 (22\% of variability) had high positive loadings of WUEi in relation to Cluster I, composed exclusively of the half-sib families from Toledo and almost all those from Calderona, and correlated oppositely with the negative loadings of the SLA (Table S1 in the Supplementary Materials). Cluster III, formed exclusively by Espadà half-sib families, was related to high values for the SLA (PC2) and $\mathrm{H}$ and BD (PC1). Cluster II was intermediately placed and reflected a midway response pattern with the Espadà and Calderona half-sib families.

For $\mathrm{Mg}$ treatment, the two first components explained $58 \%$ of the total trait variation. PC1 had high positive variable loadings of $\mathrm{H}, \mathrm{BD}$, and gs and negative loadings of the SLA (Table S1 in the Supplementary Materials). PC2 had high positive loadings of A. Cluster I was related to high gs values and lower SLA values. Cluster III was inversely related to Cluster I, with high SLA and lower gs values. Cluster II was located between both groups. No clear association appeared between the response pattern and populations, with all the groups composed of the half-sib families from the three populations.

One big group was found for Ca treatment (Cluster I), which included almost all the half-sib families and a second group, Cluster II, composed of only three half-sib families (T2, E3 and C5). The first two principal components explained $61 \%$ of the total trait variation and, as with $\mathrm{Mg}$ treatment, no clear distribution pattern was found according to populations (Figure 1; Table S1 in the Supplementary Materials).

\section{Discussion}

The three cork oak populations herein compared showed different morphological and physiological responses to drought and soil chemistry. The seedlings from both introgressed populations performed similarly over the range of growing conditions in some traits compared to the non-introgressed cork oak population. However, when considering half-sib families within populations, the population effect diminished, which reveals the importance of intra-population variation. Nevertheless, some functional traits retained their relevance at population level, pointing out the importance of some adaptation processes.

\subsection{The Role of Population in Cork Oak Seedling Performance}

Seed provenance influenced cork oak seedlings' growth in height and basal diameter. On average, the seedlings from Espadà, the population with wetter conditions, had greater aboveground growth than the seedlings from the other two populations. Conversely, the seedlings from Toledo, the more xeric population, developed a bigger belowground biomass, more sclerophyllous leaves (i.e., lower SLA) and a higher WUEi. All these traits are related to water scarcity adaptation [48]. Our population results agree with previous studies, in which the geographical and climatic characteristics influenced several populations of conifer species [49,50] and other oak species (e.g., Q. ilex in [51,52]; Q. coccifera in [33]). Specifically for cork oak, several provenance tests have demonstrated the occurrence of species' local variability for phenotypic and ecophysiological traits, such as photochemical efficiency of photosystemII [53], phenotypic differentiation according to morphological traits (i.e., plant architecture) [54], leaf ecophysiological traits [55], or budburst timing [56]. Thus, the differential selection pressures produced by environmental forces may drive populations to become differentiated as they adapt to local conditions [57]. Although trait variation is frequently associated with environmental gradients, the natural selection and evolutionary history of the species' past may also contribute to this trait differentiation [58]. Accordingly, the gene flow among species via introgression is expected to affect intraspecific differentiation patterns. In our case, when we compared between populations, the seedlings from both introgressed populations (Espadà and Calderona) performed similarly for 
some morphological and ecophysiological traits. The seedlings from the non-introgressed population in Toledo performed differently. Analyzing the traits overall, Calderona occupies an intermediate position between the wettest population (i.e., Espadà) and the driest one (i.e., Toledo). However, no general rule about morphological features of cork oak individuals introgressed with holm oak can be taken from previous studies. Putative hybrids with parental morphology [40,59,60], intermediate morphology $[59,61]$, or leaf morphology that skewed towards holm oak [60] have been reported. Other authors report no holm oak characteristics in growth and plant architecture traits, which suggests that, in some cases, gene exchange has a limited effect on cork oak population differentiation [57].

\subsection{The Role of the Half-Sib Family in the Cork Oak Seedling Response to Drought and Soil Chemistry}

Despite the differences found among populations, when considering variation across half-sib families within populations (an assessment of genotypic variation), we detected stronger differences across genotypes than across populations. These results suggest that even within relatively fragmented populations, there is significant potential to adapt to future climates.

The extent of the intra-population variability of functional traits on local scales, in response to environmental variability, has been previously highlighted by several studies [62,63]. It has been specifically suggested for cork oak that divergent selective pressures may lead to local adaptations and can also shape the genetic diversity level within populations [64]. In our study, differences in morphological features, such as seedling height and basal diameter, disappeared at the population level and were established among the half-sib families within populations. The same occurred for the photosynthesis rate, while other physiological traits, like gs and WUEi, whose significance was also lost at the population level, were only marginally significant for the half-sib families within populations. These results suggest the influence of the half-sib family factor on functional traits compared to the population level, and how it determines functional characteristics in offspring. The wide variability found at the half-sib family level would allow populations to retain a large amount of genetic diversity to face different environmental pressures [55], which is potentially important for future speciation processes within populations $[65,66]$.

Although the effect of population vanished when considering half-sib families within populations, the seedlings that best performed in aboveground growth traits (i.e., seedling height and basal diameter) or a high SLA were related mainly to the Espadà half-sib families and some half-sib families from the Calderona population, as shown in the clustering plotted in the PCA. The traits linked with water scarcity adaptation were associated mostly with the half-sib families from Toledo and some others from Calderona. These results reflect some diversification at the population level, where some individuals showed dominant traits, while others retained intra-population variability for the same traits, which may be important to cope with future climate conditions or population spreading processes $[67,68]$.

The response of cork oak seedlings to drought has been related to the climatic conditions of the site where they thrive [69]. In this study, seedling survival rate under drought was higher in populations from dry areas than in populations from mesic areas. In our study, we found no effect of drought on the morpho-functional traits of some half-sib families, regardless of the site where they thrive. However, the half-sib family and treatment interaction was significant for all the studied traits, which highlights that not all half-sib families responded in the same way or at the same intensity. These results explained the segregation of some half-sib families from different populations in the PCA, as explained above (i.e., several Toledo and Calderona half-sib families contrasted with the Espadà half-sib families). In fact, some half-sib families from Espadà, which was the wettest population, showed larger seedling size and higher SLA under drought than the other families. These findings suggest that traits related to biomass accumulation have been favored in these half-sib families from the population of the least water-stressed site. Our results agree with other studies conducted in cork oak, like that by Ramírez-Valiente et al. [64], who found a negative correlation between the SLA and annual shoot growth, or that by Besson et al. [70], who observed opposite trends among the SLA, crown volume, and the projected crown area. 
On the contrary, one cluster was composed mainly of half-sib families from Toledo, (i.e., the driest population) and Calderona, which in the drought treatment were clearly related to drought-adaptation traits, such as WUEi, conversely to the SLA, and were partially related to the high R:S ratio. WUEi is known to be positively related to water stress tolerance [71] as it is expected to be favoured when decreasing water loss allows plants to avoid dehydration and to extend water use over longer periods [72]. Furthermore, greater WUEi has the potential to support higher carbon gain and growth in relation to the amount of water used by plants [73]. In the same way, a lower SLA has long been shown to be an adaptive response to drought [74], with fitness benefits in dry environments, as more sclerophyllous leaves enable more conservative water use by preserving photosynthetic activity and carbon gain over longer periods [75]. Root: shoot biomass allocation is another key trait that indicates allocation adjustments to favour the rooting system [76], which may improve access to soil water and a better water balance [77]. In addition, cork oak is a deep-rooting species and high root allocation would act as a reservoir of stored carbohydrates to facilitate rapid regrowth after disturbances like fires, which are frequent in arid regions [78]. It is important to underline that the SLA and R:S ratio not only established significant differences at the half-sib family level, but also kept them at the population level after considering the half-sib family factor in the statistical analysis, which highlights the relevance of some traits at the population level.

Concerning soil chemistry, the addition of $\mathrm{MgCO}_{3}$ and $\mathrm{CaCO}_{3}$ very differently affected the trait response and showed no clear pattern among the half-sib families within different populations. Regarding morphological traits, Mg inputs negatively affected seedling growth in the basal diameter, which agrees with previous studies where the cork oak seedlings that were planted on soil derived from dolomites also showed poor growth [27]. Surprisingly, Ca inputs, which should have been taken as the most alkaline substrate with active carbonates, had a neutral effect on these traits, except for the Calderona population, where the addition of $\mathrm{CaCO}_{3}$ to the soil notably led to benefits for the growth variables of some sib-half families. Considering that soils in Calderona are neutral to slightly alkaline, the positive response to $\mathrm{CaCO}_{3}$ inputs in seedlings growing in this location may reflect some degree of adaptation to alkaline conditions. Our results contrast with those reported by Serrasolses et al. [27], who obtained poor performing cork oak seedlings growing on alkaline soils and confirmed this species' calcifugous character. In their study, the seedlings growing on acidic soils displayed a healthy state and had the highest grow rates, unlike the carbonated soils showing generalised iron chlorosis.

Below the ground level, the R:S ratio was positively affected by $\mathrm{Mg}$ and Ca addition compared to control seedlings. However, the half-sib family and treatment interaction was significant, which implies that not all the half-sib families responded similarly. The PCA plots denoted that some half-sib families from Toledo increased the biomass allocation to R:S, which was also related to a drop in the SLA. This could appear, as it did with drought, as an adaptive mechanism to withstand stress under unfavourable substrate conditions [76], which would match our hypothesis. Similar findings were observed for ecophysiological responses, with a general negative effect on $\mathrm{A}$ for $\mathrm{MgCO}_{3}$ addition, and a marginally positive effect on gs with $\mathrm{CaCO}_{3}$ in relation to some half-sib families from Toledo and Espadà. Overall, our results did not find a clear pattern of differentiation, especially in the $\mathrm{CaCO}_{3}$ treatment, failing our initial hypothesis that seedlings from both introgressed populations would perform better under $\mathrm{CaCO}_{3}$ and $\mathrm{MgCO}_{3}$. These results are contrary to Serrasolses et al.'s findings [27] and López de Heredia et al. [38], who suggested that the acidophilous cork oak was able to colonise the calcareous area of eastern Iberia thanks to hybridisation with holm oak, which is largely indifferent to the nature of soil. However, these results should be carefully interpreted because they could be the effect of the short nursery growing period with these treatments, and the effect of acorn reserves that could mask the soil effect in relation to nutrient supply in young seedlings [79].

\section{Conclusions}

By considering an adaptive management of cork oak forests, the selection of proper cork oak half-sib lines within each population would be extremely relevant for future reforestation programmes. 
This especially applies when forests are outside the core area of a species' distribution and are particularly sensitive to the projected climate conditions. For instance, selecting local half-sib families with a bigger aboveground biomass, as observed mainly in the half-sib families from Espadà, could be selected for productive sites with a high water availability, as these traits are generally related to higher germination rates and interspecific competitive ability [80]. In contrast, seedlings from parent plants with more sclerophyllous leaves and greater biomass allocation belowground, as observed in some half-sib families from Toledo, may be more suited for restoring water-limited sites, because they could root deeper and conserve water $[33,81,82]$.

Differences between populations and half-sib families suggest that the genetic introgression of cork oak by holm oak must play a major role in determining the genetic variation pattern observed at present, and several authors have encouraged conservation programmes to take this into account. However, we found no clear pattern in response to the manipulated soil chemistry conditions. Nevertheless, the conservation of such marginal populations must be relevant because they may hold a large proportion of the relevant genetic diversity for evolutionary processes and acclimation to future conditions [66]. Further studies with longer exposures to alterations in water regime and soil chemistry composition should be conducted to better estimate the effect of genetic introgression on seedling adaptation.

Supplementary Materials: The following are available online at http://www.mdpi.com/1999-4907/11/6/680/s1, Figure S1. Dendrograms representing the different clusters (in Roman numerals) for each treatment (Co, Control; D, drought; $\mathrm{Mg}, \mathrm{MgCO}_{3}$, inputs; $\mathrm{Ca}, \mathrm{CaCO}_{3}$, inputs). Figure $\mathrm{S} 2$. Average values and post hoc test for seedling height $(\mathrm{H})$, basal diameter (BD), root:shoot ratio (R:S), specific leaf area (SLA), stomatal conductance (gs), transpiration rate (Tr), net photosynthesis rate (A), and instantaneous water-use efficiency (WUEi) for each population and each applied treatment. Figure S3. Average values for seedling height $(\mathrm{H})$, root:shoot ratio (R:S), specific leaf area (SLA), and instantaneous water-use efficiency (WUEi) for each half-sib family within populations and each applied treatment. Table S1. Variable loadings of each trait on the first two principal components (PC) at the half-sib family level.

Author Contributions: Conceptualisation, L.M., J.C. and A.V.; methodology, L.M., H.M., J.C. and A.V.; software, L.M. and H.M.; formal analysis, L.M. and H.M.; investigation, L.M., J.C. and A.V.; resources, J.C.; data curation, L.M.; writing — original draft preparation, L.M.; writing—review and editing, L.M. and A.V.; supervision, J.C. and A.V.; project administration, J.C. and A.V.; funding acquisition, J.C. All authors have read and agreed to the published version of the manuscript.

Funding: This research has been supported by the European CREOAK Project (QLRT-2001-01594) and the IMAGINA-PROMETEO Project (PROMETEU/2019/110) funded by the Generalitat Valenciana. JC acknowledges the support from Ministerio de Ciencia, Innovación y Universidades, project Cost-effectiveness analysis of restoration actions (COSTERA; RTI2018-095954-B-I00). The CEAM Foundation is supported by the Generalitat Valenciana.

Acknowledgments: We thank V. Ramón Vallejo for his helpful suggestions about the article, and Marian Pérez-Devesa, Román Trubat, and Tadas Bitinas for their help in setting up the experiment, treatment implementation, and data collection. We also thank Felipe Gil (SSTT, Generalitat Valenciana) and the Santa Faz nursery for their facilities to carry out this experiment.

Conflicts of Interest: The authors declare no conflict of interest. The funders had no role in the design of the study; in the collection, analyses, or interpretation of data; in the writing of the manuscript, or in the decision to publish the results.

\section{References}

1. Giorgi, F; Lionello, P. Climate change projections for the Mediterranean region. Glob. Planet. Chang. 2008, 63, 90-104. [CrossRef]

2. Reynolds, J.F.; Smith, D.M.S.; Lambin, E.F.; Turner, B.L.; Mortimore, M.; Batterbury, S.P.; Downing, T.E.; Dowlatabadi, H.; Fernández, R.J.; Herrick, J.E.; et al. Global desertification: Building a science for dryland development. Science 2007, 316, 847-851. [CrossRef]

3. Peñuelas, J.; Lloret, F.; Montoya, R. Severe drought effects on Mediterranean woody flora in Spain. For. Sci. 2001, 47, 214-218. [CrossRef]

4. Nardini, A.; Ghirardelli, L.; Salleo, S. Vulnerability to freeze stress of seedlings of Quercus ilex L.: An ecological interpretation. Ann. For. Sci. 1998, 55, 553-565. [CrossRef] 
5. Olarieta, J.R.; Rodríguez-Ochoa, R.; Ascaso, E. Soil gypsum and increased penetration resistance restrict early growth of Quercus ilex plantations. Arid Land Res. Manag. 2012, 26, 250-260. [CrossRef]

6. Gómez-Aparicio, L.; Ibáñez, B.; Serrano, M.S.; De Vita, P.; Ávila, J.M.; Pérez-Ramos, I.M.; García, L.V.; Sánchez, M.E.; Marañón, T. Spatial patterns of soil pathogens in declining Mediterranean forests: Implications for tree species regeneration. New Phytol. 2012, 194, 1014-1024. [CrossRef] [PubMed]

7. Morcillo, L.; Gallego, D.; González, E.; Vilagrosa, A. Forest decline triggered by phloem parasitism-related biotic factors in Aleppo pine (Pinus halepensis). Forests 2019, 10, 608. [CrossRef]

8. Vicente-Serrano, S.M.; Quiring, S.M.; Peña-Gallardo, M.; Yuan, S.; Domínguez-Castro, F. A review of environmental droughts: Increased risk under global warming? Earth-Sci. Rev. 2020, 201, 102953. [CrossRef]

9. Correia, R.A.; Bugalho, M.N.; Franco, A.M.A.; Palmeirim, J.M. Contribution of spatially explicit models to climate change adaptation and mitigation plans for a priority forest habitat. Mitig. Adapt. Strat. Glob. Chang. 2018, 23, 371-386. [CrossRef]

10. López-Tirado, J.; Vessella, F.; Schirone, B.; Hidalgo, P.J. Trends in evergreen oak suitability from assembled species distribution models: Assessing climate change in south-western Europe. New For. 2018, 49, 471-487. [CrossRef]

11. Acácio, V.; Dias, F.S.; Catry, F.X.; Rocha, M.; Moreira, F. Landscape dynamics in Mediterranean oak forests under global change: Understanding the role of anthropogenic and environmental drivers across forest types. Glob. Chang. Biol. 2017, 23, 1199-1217. [CrossRef] [PubMed]

12. Vessella, F.; López-Tirado, J.; Simeone, M.C.; Schirone, B.; Hidalgo, P.J. A tree species range in the face of climate change: Cork oak as a study case for the Mediterranean biome. Eur. J. For. Res. 2017, 136, 555-569. [CrossRef]

13. Montero, G.; Cañellas, I. Selvicultura de los alcornocales en España. Silva Lusit. 2003, 11, 1-19.

14. Olea, L.; San Miguel-Ayanz, M.A. The Spanish dehesa. A traditional Mediterranean silvopastoral system linking production and nature conservation. Grassl. Sci. Eur. 2006, 11, 3-13.

15. Pausas, J.G. Resprouting of Quercus suber in NE Spain after fire. J. Veg. Sci. 1997, 8, 703-706. [CrossRef]

16. Camilo-Alves, C.S.P.; Da Clara, M.I.E.; Ribeiro, N.M.D.A. Decline of Mediterranean oak trees and its association with Phytophthora cinnamomi: A review. Eur. J. For. Res. 2013, 132, 411-432. [CrossRef]

17. Ibáñez, B.; Gómez-Aparicio, L.; Ávila, J.M.; Pérez-Ramos, I.M.; Marañón, T. Effects of Quercus suber decline on woody plant regeneration: Potential implications for successional dynamics in Mediterranean forests. Ecosystems 2017, 20, 630-644. [CrossRef]

18. Camilo-Alves, C.S.P.; Vaz, M.; Da Clara, M.I.E.; Ribeiro, N.M.D.A. Chronic cork oak decline and water status: New insights. New For. 2017, 48, 753-772. [CrossRef]

19. Sánchez, M.E.; Caetano, P.; Romero, M.A.; Navarro, R.M.; Trapero, A. Phytophthora root rot as the main factor of oak decline in southern Spain. In Progress in Research on phytophthora Diseases of Forest Trees; Brasier, C., Jung, T., Oßwald, W., Eds.; Forest Research: Farnham, UK, 2006; pp. 149-154.

20. Hufford, K.M.; Mazer, S.J. Plant ecotypes: Genetic differentiation in the age of ecological restoration. Trends Ecol. Evol. 2003, 18, 147-155. [CrossRef]

21. Chazdon, R.L. Beyond deforestation: Restoring forests and ecosystem services on degraded lands. Science 2008, 320, 1458-1460. [CrossRef]

22. Bakkenes, M.; Alkemade, J.R.M.; Ihle, F.; Leemans, R.; Latour, J.B. Assessing effects of forecasted climate change on the diversity and distribution of European higher plants for 2050. Glob. Chang. Biol. 2002, 8, 390-407. [CrossRef]

23. Hällfors, M.H.; Aikio, S.; Schulman, L.E. Quantifying the need and potential of assisted migration. Biol. Conserv. 2017, 205, 34-41. [CrossRef]

24. Prober, S.M.; Byrne, M.; McLean, E.H.; Steane, D.A.; Potts, B.M.; Vaillancourt, R.E.; Stock, W.D. Climate-adjusted provenancing: A strategy for climate-resilient ecological restoration. Front. Ecol. Evol. 2005, 3, 65. [CrossRef]

25. Mediavilla, S.; Escudero, A. Stomatal responses to drought at a Mediterranean site: A comparative study of co-occurring woody species differing in leaf longevity. Tree Physiol. 2003, 23, 987-996. [CrossRef] [PubMed]

26. Corcuera, L.; Morales, F.; Abadía, A.; Gil-Pelegrín, E. Seasonal changes in photosynthesis and photoprotection in a Quercus ilex subsp. ballota woodland located in its upper altitudinal extreme in the Iberian Peninsula. Tree Physiol. 2005, 25, 599-608. [CrossRef] [PubMed] 
27. Serrasolses, I.; Pérez-Devesa, M.; Vilagrosa, A.; Pausas, J.G.; Sauras, T.; Cortina, J.; Vallejo, V.R. Soil Properties Constraining Cork Oak Distribution in Cork Oak Woodlands on the Edge; Aronson, J., Pereira, J.S., Pausas, J.G., Eds.; Island Press: Washington, DC, USA, 2009; pp. 89-101.

28. Eriksson, G.; Namkoong, G.; Roberds, J.H. Dynamic gene conservation for uncertain futures. For. Ecol. Manag. 1993, 62, 15-37. [CrossRef]

29. Krichen, K.; Vilagrosa, A.; Chaieb, M. Divergence of functional traits at early stages of development in Stipa tenacissima populations distributed along an environmental gradient of the Mediterranean. Plant Ecol. 2019, 220, 995-1008. [CrossRef]

30. Leimu, R.; Fischer, M. A meta-analysis of local adaptation. Plants. PLoS ONE 2008, 3, e4010. [CrossRef]

31. Lampei-Bucharová, A.; Michalski, S.G.; Hermann, J.M.; Heveling, K.; Durka, W.; Hölzel, N.; Kollmann, J.; Bossdorf, $\mathrm{O}$. Genetic differentiation and regional adaptation among seed origins used for grassland restoration: Lessons from a multi-species transplant experiment. J. Appl. Ecol. 2017, 54, 127136. [CrossRef]

32. Bischoff, A.; Steinger, T.; Müller-Schärer, H. The importance of plant provenance and genotypic diversity of seed material used for ecological restoration. Restor. Ecol. 2008, 18, 338-348. [CrossRef]

33. Pastor, E.; Soliveres, S.; Vilagrosa, A.; Bonet, A. Intraspecific leaf shape at local scale determines offspring characteristics. J. Arid Environ. 2018, 153, 18-23. [CrossRef]

34. Lumaret, R.; Jabbour-Zahab, R. Ancient and current gene flow between two distantly related Mediterranean oak species, Quercus suber and Q. ilex. Ann. Bot. 2009, 104, 725-736. [CrossRef]

35. Cronn, R.; Wendel, J. Cryptic trysts, genome mergers, and plant speciation. New Phytol. 2004, 161, $133-142$. [CrossRef]

36. Petit, R.J.; Bodénès, C.; Ducousso, A.; Roussel, G.; Kremer, A. Hybridization as a mechanism of invasion in oaks. New Phytol. 2004, 161, 151-164. [CrossRef]

37. Mallet, J. Hybrid speciation. Nature 2007, 446, 279-283. [CrossRef]

38. López de Heredia, U.; Carrion, J.S.; Jimenez, P.; Collada, C.; Gil, L. Molecular and palaeoecological evidence for multiple glacial refugia for evergreen oaks on the Iberian Peninsula. J. Biogr. 2007, 34, 1505-1517. [CrossRef]

39. Soto, A.; López de Heredia, U.; Robledo-Arnuncio, J.J.; Gil, L. Simulation analysis of Quercus Ilex-Quercus Suber chloroplast introgression. In Suberwood: New Challenges for the Integration of Cork Oak Forests and Products; Vázquez-Piqué, J., Pereira, H., González Pérez, M.M., Eds.; Universidad de Huelva: Madrid, Spain, 2008; pp. 91-97.

40. Belahbib, N.; Pemonge, M.H.; Ouassou, A.; Sbay, H.; Kremer, A.; Petit, R.J. Frequent cytoplasmic exchanges between oak species that are not closely related: Quercus suber and Q. ilex in Morocco. Mol. Ecol. 2001, 10, 2003-2012. [CrossRef]

41. Magri, D.; Fineschi, S.; Bellarosa, R.; Buonamici, A.; Sebastiani, F.; Schirone, B.; Simeone, M.C.; Vendramin, G.G. The distribution of Quercus suber chloroplast haplotypes matches the palaeogeographical history of the western Mediterranean. Mol. Ecol. 2007, 16, 5259-5266. [CrossRef]

42. Mir, C.; Jarne, P.; Sarda, V.; Bonin, A.; Lumaret, R. Contrasting nuclear and cytoplasmic exchanges between phylogenetically distant oak species (Quercus suber L. and Q. ilex L.) in Southern France: Inferring crosses and dynamics. Plant Biol. 2009, 11, 213-226. [CrossRef]

43. Jiménez, P.; Agúndez, D.; Alía, R.; Gil, L. Genetic variation in central and marginal populations of Quercus suber L. Silvae Genet. 1999, 48, 278-284.

44. De Martonne, E. Géographie Physique (Physical Geography), 3rd ed.; Armand Colin: Paris, France, 1920.

45. González-Martinez, S.C.; Burczyk, J.; Nathan, R.; Nanos, N.; Gil, L.; Alía, R. Effective gene dispersal and female reproductive success in Mediterranean maritime pine (Pinus pinaster Aiton). Mol. Ecol. 2006, 15, 4577-4588. [CrossRef] [PubMed]

46. R Core Team. R: A Language and Environment for Statistical Computing; R Foundation for Statistical Computing: Vienna, Austria, 2020; Available online: https://www.R-project.org/ (accessed on 29 February 2020).

47. Suzuki, R.; Hidetoshi, S. Pvclust: Hierarchical Clustering with P-Values via Multiscale Bootstrap Resampling. 2019. Available online: https://CRAN.R-project.org/package=pvclust (accessed on 3 April 2020).

48. Osnas, J.L.; Lichstein, J.W.; Reich, P.B.; Pacala, S.W. Global leaf trait relationships: Mass, area, and the leaf economics spectrum. Science 2013, 340, 741-744. [CrossRef] [PubMed]

49. Bongarten, B.C.; Hanover, J.W. Provenance variation in blue spruce (Picea pungens) at eight locations in the northern Unites States and Canada. Silvae Genet. 1986, 35, 2-3. 
50. Strandby, U.; Prado, J.P.; Bräuner, U.; Kollman, J. Provenance variation in germination growth of Abies guatemalensis Reher. For. Ecol. Manag. 2008, 255, 1831-1840. [CrossRef]

51. Gratani, L.; Meneghini, M.; Pesoli, P.; Crescente, M.F. Structural and functional plasticity of Quercus ilex seedlings of different provenances in Italy. Trees Struct. Funct. 2003, 17, 515-521. [CrossRef]

52. Peguero-Pina, J.J.; Sancho-Knapik, D.; Barrón, E.; Camarero, J.J.; Vilagrosa, A.; Gil-Pelegrín, E. Morphological and physiological divergences within Quercus ilex support the existence of different ecotypes depending on climatic dryness. Ann. Bot. 2014, 114, 301-313. [CrossRef]

53. Aranda, I.; Castro, L.; Alía, R.; Pardos, J.A.; Gil, L. Low temperature during winter elicits differential responses among populations of the Mediterranean evergreen cork oak (Quercus suber). Tree Physiol. 2005, 25, 1085-1090. [CrossRef]

54. Gandour, M.; Khouja, M.L.; Toumi, L.; Triki, S. Morphological evaluation of cork oak (Quercus suber): Mediterranean provenance variability in Tunisia. Ann. For. Sci. 2007, 64, 549-555. [CrossRef]

55. Ramírez-Valiente, J.A.; Sánchez-Gómez, D.; Aranda, I.; Valladares, F. Phenotypic plasticity and local adaptation in leaf ecophysiological traits of 13 contrasting cork oak populations under different water availabilities. Tree Physiol. 2010, 30, 618-627. [CrossRef]

56. Sampaio, T.; Branco, M.; Guichoux, E.; Petit, R.J.; Pereira, J.S.; Varela, M.C.; Almeida, M.H. Does the geography of cork oak origin influence budburst and leaf pest damage? For. Ecol. Manag. 2016, 373, 33-43. [CrossRef]

57. Ramirez-Valiente, J.A.; Alia, R.; Aranda, I. Geographical variation in growth form traits in Quercus suber and its relation to population evolutionary history. Evol. Ecol. 2014, 28, 55-68. [CrossRef]

58. Svenning, J.C.; Skov, F. The relative roles of environment and history as controls of tree species composition and richness in Europe. J. Biogeogr. 2005, 32, 1019-1033. [CrossRef]

59. Toumi, L.; Lumaret, R. Allozyme variation in cork oak (Quercus suber L.): The role of phylogeography and genetic introgression by other Mediterranean oak species and human activities. Theor. Appl. Genet. 1998, 97, 647-656. [CrossRef]

60. Staudt, M.; Mir, C.; Joffre, R.; Rambal, S.; Bonin, A.; Landais, D.; Lumaret, R. Isoprenoid emissions of Quercus spp. (Q.suber and Q.ilex) in mixed stands contrasting in interspecific genetic introgression. New Phytol. 2004, 163, 573-584. [CrossRef]

61. Bellarosa, R.; Simeone, M.C.; Papini, A.; Schirone, B. Utility of ITS sequence data for phylogenetic reconstruction of Italian Quercus spp. Mol. Phylogenetics Evol. 2005, 34, 355-370. [CrossRef] [PubMed]

62. Harzé, M.; Mahy, G.; Monty, A. Functional traits are more variable at the intra-than inter-population level: A study of four calcareous dry-grassland plant species. Tuexenia 2016, 36, 321-336.

63. Vastag, E.; Cocozza, C.; Orlović, S.; Kesić, L.; Kresoja, M.; Stojnić, S. Half-sib lines of pedunculate oak (Quercus robur $\mathrm{L}$.) respond differently to drought through biometrical, anatomical and physiological traits. Forests 2020, 11, 153. [CrossRef]

64. Ramírez-Valiente, J.A.; Valladares, F.; Huertas, A.D.; Granados, S.; Aranda, I. Factors affecting cork oak growth under dry conditions: Local adaptation and contrasting additive genetic variance within populations. Tree Genet. Genomes 2011, 7, 285-295. [CrossRef]

65. Givnish, T.J. Ecology of plant speciation. Taxon 2010, 59, 1326-1366. [CrossRef]

66. Zeng, Y.F.; Liao, W.J.; Petit, R.J.; Zhang, D.Y. Geographic variation in the structure of oak hybrid zones provides insights into the dynamics of speciation. Mol. Ecol. 2011, 20, 4995-5011. [CrossRef]

67. Hewitt, G.M. Genetic consequences of climatic changes in the Quaternary. Philos. Trans. R. Soc. Lond. B 2004, 359, 183-195. [CrossRef] [PubMed]

68. Hampe, A.; Petit, R.J. Conserving biodiversity under climate change: The rear edge matters. Ecol. Lett. 2005, 8, 461-467. [CrossRef] [PubMed]

69. Ramírez-Valiente, J.A.; Valladares, F.; Gil, L.; Aranda, I. Population differences in juvenile survival under increasing drought are mediated by seed size in cork oak (Quercus suber L.). For. Ecol. Manag. 2009, 257, 1676-1683. [CrossRef]

70. Besson, C.K.; Lobo do Vale, R.; Rodrigues, M.L.; Almeida, P.; Herd, A.; Grant, O.M.; Soares-David, T.; Schmidt, M.; Otieno, D.; Keenan, T.F.; et al. Cork oak physiological responses to manipulated water availability in a Mediterranean woodland. Agric. For. Meteorol. 2014, 184, 230-242. [CrossRef]

71. Ferrio, J.P.; Florit, A.; Vega, A.; Serrano, L.; Voltas, J. $813 \mathrm{C}$ and tree-ring width reflect different drought responses in Quercus ilex and Pinus halepensis. Oecologia 2003, 442, 512-518. [CrossRef] 
72. Donovan, L.A.; Dudley, S.A.; Rosenthal, D.M.; Ludwig, F. Phenotypic selection on leaf water use efficiency and related ecophysiological traits for natural populations of desert sunflowers. Oecologia 2007, 152, 13-25. [CrossRef]

73. Leakey, A.D.; Ferguson, J.N.; Pignon, C.P.; Wu, A.; Jin, Z.; Hammer, G.L.; Lobell, D.B. Water use efficiency as a constraint and target for improving the resilience and productivity of $\mathrm{C}_{3}$ and $\mathrm{C}_{4}$ crops. Annu. Rev. Plant Biol. 2019, 70, 781-808. [CrossRef]

74. Grünzweig, J.M.; Carmel, Y.; Riov, J.; Sever, N.; McCreary, D.D.; Flather, C.H. Growth, resource storage, and adaptation to drought in California and eastern Mediterranean oak seedlings. Can. J. For. Res. 2008, 38, 331-342. [CrossRef]

75. Dudley, S.A. Differing selection on plant physiological traits in response to environmental water availability: A test of adaptive hypotheses. Evolution 1996, 50, 92-102. [CrossRef]

76. Otieno, D.O.; Besson, C.K.; Liu, J.; Schmidt, M.W.T.; Lobo do Vale, R.; David, T.S.; Siegwolf, R.; Pereira, J.S.; Tenhunenet, J.D. Seasonal variations in soil and plant water status in a Quercus suber L. Stand: Roots as determinants of tree productivity and survival in the Mediterranean-type ecosystem. Plant Soil 2006, 283, 119-135. [CrossRef]

77. Nepstad, D.C.; de Carvalho, C.R.; Davidson, E.A.; Jipp, P.H.; Lefebvre, P.A.; Negreiros, G.H.; da Silva, E.D.; Stone, T.A.; Trumbore, S.E.; Vieira, S. The role of deep roots in the hydrological and carbon cycles of Amazonian forests and pastures. Nature 1994, 372, 666-669. [CrossRef]

78. Ryan, C.M.; Williams, M.; Grace, J. Above-and belowground carbon stocks in a miombo woodland landscape of Mozambique. Biotropica 2011, 43, 423-432. [CrossRef]

79. Villar-Salvador, P.; Heredia, N.; Millard, P. Remobilization of acorn nitrogen for seedling growth in holm oak (Quercus ilex), cultivated with contrasting nutrient availability. Tree Physiol. 2010, 30, 257-263. [CrossRef]

80. Collet, C.; Manso, R.; Barbeito, I. Coexistence, association and competitive ability of Quercus petraea and Quercus robur seedlings in naturally regenerated mixed stands. For. Ecol. Manag. 2017, 390, 36-46. [CrossRef]

81. Padilla, F.M.; Pugnaire, F.I. Rooting depth and soil moisture control Mediterranean woody seedling survival during drought. Funct. Ecol. 2007, 21, 489-495. [CrossRef]

82. Trubat, R.; Cortina, J.; Vilagrosa, A. Nutrient deprivation improves field performance of woody seedlings in a degraded semi-arid shrubland. Ecol. Eng. 2011, 37, 1164-1173. [CrossRef] 